\title{
서해안의 태풍해일특성과 고극조위 \\ Typhoon-Surge Characteristics and the Highest High Water Levels at the Western Coast
}

\author{
강주환* · 김양선* \\ Ju Whan Kang* and Yang-Seon Kim*
}

\begin{abstract}
요 지 : 서해안 지역에서 대형태풍에 의한 해일유형을 세 가지로 구분한 후 그 특성을 고찰하였다. 태풍 OLGA(9907) 와 KOMPASU(1007)가 대표적인 첨두형 태풍인데 빠른 이동속도로 서해안에 근접하여 통과한 태풍으로 최대해일고 발생이 조시와는 무관한 특성을 보인다. 반면 태풍 PRAPIROON(0012)과 BOLAVEN(1215) 등은 대표적인 지속형으 로서 느린 이동속도로 서해안에서 이격하여 통과한 태풍이며 주로 저조시에 최대해일고가 발생하는 조석변조해일 특성을 보인다. 한편 태풍 MUIFA(1109)와 WINNIE(9713)의 경우 지속형으로 구분될 수는 있지만, 외부에서 전파되 어 온 해일유형으로 구분되어 조석변조해일 특성은 보이지 않는다. 이러한 해일유형을 토대로 서해안 지역에서 고극 조위가 발생하는 패턴을 구분한 결과 현재까지 해면고가 가장 높았던 경우는 태풍 WINNIE(9713)와 같은 전파형의 크지 않은 해일고가 백중사리의 높은 조위조건과 겹쳐 발생한 경우였다. 향후 높은 조위조건에 첨두형 태풍이 겹칠 경우 전무후무한 고극조위가 발생할 수 있을 가능성이 다소 낮은 확률로 존재한다. 그러나 대부분의 대형태풍이 저 조시에 최대해일고가 발생하는 지속형임을 감안하면 저조시 크게 나타난 해일고를 단순히 약최고고조위에 가산하여 설계조위를 산정하는 설계법은 과다설계의 우려가 크다. 태풍해일 수치모의를 통해 극치해면고를 산정할 경우에도 가급적 다양한 조위조건을 함께 부여하여 조석-해일 비선형성이 재현되도록 해야 하며, 태풍의 이동속도와 최근접거 리에 따른 해일특성에 대한 변화양상을 주의 깊게 고찰하여야 한다.
\end{abstract}

핵심용어 : 태풍해일특성, 해일유형, 조석변조해일, 고극조위, 서해안

\begin{abstract}
The aspects of typhoon-induced surges were classified into three types at the Western coast, and their characteristics were examined. The typhoons OLGA (9907) and KOMPASU (1007) were the representative steep types. As they pass close to the coasts with fast translation velocity, the time of maximum surge is unrelated to tidal phase. However, typhoons PRAPIROON (0012) and BOLAVEN (1215) were the representative mild types, which pass at a long distance to the coasts with slow translation velocity, and were characterized by having maximum surge time is near low tide. Meanwhile, typhoons MUIFA (1109) and WINNIE (9713) can be classified into mild types, but they do not show the characteristics of the mild type. Thus they are classified into propagative type, which are propagated from the outside. Analyzing the annual highest high water level data, the highest water level ever had been recorded when the WINNIE (9713) had attacked. At that time, severe astronomical tide condition overlapped modest surge. Therefore, if severe astronomical tide encounter severe surge in the future, tremendous water level may be formed with very small probability. However, considering that most of the huge typhoons are mild type, time of maximum surge tends to occur at low tide. In case of estimating the extreme water level by a numerical simulation, it is necessary not only to apply various tide conditions and accompanying tide-modulated surge, but also to scrutinize typhoon parameters such as translation velocity and so on.
\end{abstract}

Keywords : typhoon-surge characteristics, surge type, tide-modulated surge, highest high water level, Western coast

\section{1. 서 론}

지구온난화를 포함한 기후변화가 태풍의 강도 및 빈도에 미치는 영향성과 관련된 연구들에 의하면 최근 태풍의 빈도 가 증가추세를 보인다는 연구(Clark and Chu, 2002) 뿐 아 니라 뚜렷한 변화추세를 보이지 않는다는 연구(Klotzbach,
2006) 및 오히려 감소추세 있다는 연구(Landsea et al., 1996) 등 연구자마다 의견이 갈리고 있다. 그러나 이들 연 구에서 제기되고 있는 공통된 의견은 태풍의 강도는 점차 증 가하는 추세에 있다는 사실이다. 즉, 21세기 들어 전세계적 으로 더욱 강력해지는 태풍으로 인한 피해가 속출하고 있으 며 2013년에는 역사상 가장 강한 태풍인 하이옌이 필리핀

*목포대학교 토목공학과(Corresponding author: Ju Whan Kang, Dept. of Civil Engineering, Mokpo National University, 1666 Yeongsan-ro, Cheonggye-myeon, Muan-gun, Jeonnam 58554, Korea, Tel: +82-61-450-2473, Fax: +82-61-452-6468, jwkang@mokpo.ac.kr) 
에 상륙한 바 있다. IPCC 5 차 보고서(IPCC, 2013)에 따르 면 금세기말 전지구적으로 태풍의 발생빈도가 늘지는 않겠 지만 태풍강도는 증가할 것으로 예측하고 있으며, 수치모델 에 의한 추산 결과 역시 2100 년까지 태풍강도의 증가율이 $2 \sim 11 \%$ 에 이를 것으로 예상하고 있다(Feng and Tsimplis, 2014).

한반도 주변도 예외는 아니어서 이러한 태풍환경변화에 의 해 일본의 경우 RCP8.5 시나리오 조건에서 1959년 발생했 던 태풍 $\mathrm{VERA}$ 의 최저기압 $900 \mathrm{hPa}$ 이 미래조건에서 $879 \mathrm{hPa}$ 까지 강해질 수 있다는 연구결과(Mori and Takemi, 2016)가 제시되고 있다. 더불어 한반도 역시 수치모형을 이용한 관련 연구(Oh and Moon, 2013)에 따르면 태풍 MAEMI(2003)와 RUSA(2002)의 경우 미래기후환경에서 각각 $19 \mathrm{hPa}$ 및 17 $\mathrm{hPa}$ 정도 중심기압이 더욱 낮아지는 것으로 예측하고 있다. 또한 Yang et al.(2018)의 연구 역시 한반도에 내습하는 태풍 횟수가 1년에 1.08 번에서 0.67 번으로 감소하겠지만 태풍강도 는 증가하여 $10 \mathrm{hPa}$ 정도 중심기압이 낮아지는 것으로 예측 하고 있다. 지구온난화에 따라 한반도 주변 해수온도가 증가 일로에 있음을 감안하면 한반도로 접근하는 태풍의 에너지원 인 따뜻한 수증기의 공급이 원활해짐에 따라 한반도 남단에 미치는 태풍의 영향이 점점 더 강력해지는 것은 충분히 수긍 할 수 있는 현상이라 할 수 있다. 이와 함께 황해로 진입하 는 태풍 역시 금방 쇠락했던 예전과는 달리 어느 정도 강한 세력을 유지한 채로 우리나라 서해안에 큰 영향을 미치는 경 우가 점점 늘게 될 전망이다. 이러한 내용은 태풍의 주된 경 로가 북서쪽으로 이동하는 것으로 예측한 연구결과(Yang et al., 2018)와도 일맥상통한 것이다. 이와 같이 태풍내습횟수는 감소하겠지만 서해안으로 향하는 강력한 태풍이 잦을 것으로 예측됨에 따라 발생되는 해일고 역시 특히 서해안에서 두드 러지게 증가할 것으로 전망된다.

일반적으로 태풍이 상륙할 경우 진행방향의 우측반원을 위 험반원이라 하여 가항반원인 좌측반원에 비해 풍속도 매우 강 할 뿐 아니라 해일고도 크게 나타난다. 이와 같이 태풍경로 에 따라서 지역적인 해일고 편차가 매우 클 뿐 아니라 서해 안으로 진입하는 태풍의 경우 태풍의 중심이 지나간 후 최대 해일고가 나타나는 경향(Kang, 2015)이 있는 등 다양한 지역 적 특성을 보이고 있다. 특히 우리나라 서해안은 조차가 매 우 커서 조석과 해일을 함께 고려해야 극치해면고에 따른 범 람해석이 가능한 동시에 조석-해일 비선형성(Kang et al., 2014; Kang, 2015)에 의한 효과도 면밀히 검토할 필요가 있 다. 따라서 본 연구에서는 미래기후환경에서 발생되는 해일 고가 크게 증가하는 것으로 예측되고 있는 서해안에서 특유 의 조석-해일 비선형성을 포함하여 다양한 태풍-해일 특성을 분석한 후 고극조위가 발생한 사례분석을 통해 고조위와 해 일의 조우상황을 면밀히 고찰한다. 이를 통해 조석이 지배적 인 해역에서 극치해면고 및 설계조위 산정에 반영될 수 있는 지침을 수립할 수 있다.

\section{2. 태풍-해일의 일반적 특성}

\section{1 기압 및 풍속}

태풍에 의한 해일은 저기압 및 바람마찰에 의에 의한 수면 상승 외에도 파랑에 의한 수면상승, 장파에 의한 수면상승, Coriolis에 의한 수면상승 등 다양한 요소가 수반되지만 일반 적으로 해일고에 가장 큰 영향을 미치는 요소는 기압과 바람 에 의한 수면상승이라 알려져 있다. 기압과 바람만 고려할 경 우 우리나라 동해안, 서해안, 남해안 각각에서 발생하는 해일 발생 양상은 사뭇 다르게 나타난다. 태풍중심에 가까울수록 기압에 의한 수면상승은 크게 나타나는 반면 바람에 의한 수 면상승은 다른 거동을 보인다. 즉, 최대풍반경 만큼 이격된 지 점에서 최대풍속이 발생되는데, 풍속 뿐 아니라 풍향에 따라 육지에 수직한 방향의 해풍성분이 가장 강할 때 해일고도 커 지게 된다. 또한 기압에 의한 수면상승은 수심에 따라 큰 변 화가 없는 반면 바람에 의한 수면상승은 풍속이 일정할 경우 다음 식(1)에서 보는 바와 같이 수심에 반비례하여 커지게 된 다. 따라서 우리나라 서해안과 같이 수심이 얕은 해안에서는 바람에 의한 해일고가 크게 형성되는 경향이 있으며 다음에 기술하는 바와 같이 기압에 의한 수면상승과 바람에 의한 수 면상승의 시점이 일치하지 않는 경우가 종종 발생한다.

$$
\partial \eta / \partial x=C W^{2} / D
$$

여기서 좌변은 수면기울기, $C$ 는 항력계수, $W$ 는 풍속, $D$ 총 수심을 의미한다.

남해안에 태풍이 상륙할 경우에는 상륙지점의 동쪽에 위치 한 위험반원에 해당하는 지점에서 기압에 의한 해일고와 바 람에 의한 해일고는 태풍상륙시점에 동시에 최대값에 이르게 된다. 즉, 태풍이 상륙하는 순간 동쪽으로 위험반원만큼 떨어 진 해안가에서는 태풍의 중심이 해당지점에 대하여 최근접거 리를 지나므로 기압에 의한 수면상승이 최대가 되는 동시에 바람에 의한 수면상승 역시 최대값을 보이게 된다. 이에 반 해 서해안 지역에서는 서해안을 일정 거리만큼 이격한 상태 로 연해서 통과하는 태풍의 경우 태풍이 해안 지역의 최근접 지점을 통과하는 시점에서 기압에 의한 해일고가 최대값에 이 르게 되지만 이 시점에서 해안지역의 풍향은 해안선에 평행 한 북쪽을 향하므로 바람에 의한 해일고는 미미한 상태이다. 태 풍이 어느 정도 더 진행한 시점에서 비로소 바다로부터 육지 로 향하는 바람성분이 최대가 되므로 이때 해풍에 의한 해안 지역의 해일고가 최대로 나타나게 된다. 따라서 남해안과 달 리 기압과 바람에 의한 해일에는 시차가 존재하며 수심이 얕 은 서해안의 특성상 바람에 의한 해일이 우세한 경우가 많아 최대해일고는 태풍 통과후 일정시간 지체후 형성되는 소위 ‘시차특성’이 발생한다(Kang and Kim, 2016). 동해안을 통과 하는 경우는 서해안과 반대로 해풍에 의한 최대해일고가 발 생한 후에 기압에 의한 해일고가 발생하여 최대해일고가 태 풍 도착전에 발생하는 경향이 있지만 서해안과 달리 수심이 
깊어 그 효과는 서해안에 비해 미미한 실정이다(Kang and Park, 2017). 한편, 육지연안에 비해 섬지역에서는 깊은 수심 에 기인하여 바람에 의한 수면상승에 비해 기압에 의한 수면 상승이 우세하게 나타나기도 한다(Seo and Kim, 2014).

이와 같이 태풍이 접근함에 따라 주로 기압과 풍속에 의한 해일이 형성되는데, 영역 부근에서 발생되는 이러한 해일성 분 외에 영역 밖에서 생성된 해일이 해당 영역으로 전파되어 유입된 성분도 함께 존재한다(Liu et al., 2018). 물론 영역 밖으로부터 유입된 해일고의 크기는 영역내에서 기압과 바람 에 의해 발생되는 해일고에 비하면 상대적으로 미미한 수준 이지만, 조석이 지배적인 서해안의 특성상 이들 역시 주의 깊 게 살펴볼 필요가 있다. 즉, 서해안에서 극치해면고가 발생하 는 경우는 조위가 그리 높지 않은 상황에서 대규모 태풍발생 에 의한 해일고가 중첩된 상황이라기보다 백중사리 시기와 같 이 매우 높은 조위상황에 크지 않은 해일고가 겹친 상황이 더 욱 일반적이기에 서해안의 경우 극치해면고 발생은 조위상황 에 민감한 반면 해일고 크기에는 다소 둔감하기 때문이다.

\section{2 조석변조해일}

서해안과 같이 조차가 크고 수심이 얕은 해역에서는 다양 한 양상으로 조석-해일 비선형성이 나타나고 있다(Kang et al., 2014; Wuxi et al., 2018). 즉, 조위에 부가하여 양의 해 일이 중첩될 경우 수심이 더욱 깊어지므로 파속이 증가하여 천문조만 존재하는 경우에 비해 조석파가 일찍 도달하게 되 는 창조집중현상이 발생할 수 있는데, 이 현상은 창조시에 조 석잔차가 크게 형성되는 경향을 의미한다. 그러나 국내에서 는 유의미한 수심변화를 초래할 정도로 해일고가 크게 형성 되는 경우는 많지 않아 창조집중현상은 뚜렷하지 않은 실정 이다.

Horsburgh and Wilson(2007)에 따르면 해일고가 가장 심 한 시점은 저조와 창조 중간 정도라고 알려져 있다. 식(1)에 제시된 바와 같이 수면의 기울기는 수심에 반비례하기 때문 에 바람에 의한 해일의 경우 저조시에 가장 크게 나타나게 되 며 천해역에서 특히 뚜렷하게 나타난다. 이러한 조석-해일 비
선형특성을 조석변조해일(tidally modulated surge)이라 하는 데, 비태풍(Kang et al., 2014) 및 태풍(Kang, 2015)에 의한 해일고 분석에 의하면 국내 서해안과 남해안에서 최대해일고 발생시점이 저조시에 빈도가 높고 고조시에 낮은 현상이 뚜 렷하게 나타나고 있다.

한편 조석의 관측이나 예측에 내재된 오차가 클 경우, 특 히 분조별 지각의 오차가 클 경우에도 조석주기로 나타나는 해일고를 검출할 수 있다(Flowerdew et al., 2010). 이에 따 라 천문조성분이 제거된 조위편차자료에 대한 웨이블릿분석 이나 FFT 분석을 시행할 경우 천문조 주기의 값이 활성화되 는 경우를 볼 수 있으며 천해조가 크게 발달된 목포해역에서 천해조 주기의 해일성분이 관측되는 것 역시 이와 무관치 않 은 것으로 추정된다. 이와 같이 조석변조해일을 포함한 조석 -해일 비선형특성의 발생기작에 의해 특히 목포를 포함한 서 해안과 일부 남서해안에서 저조시 해일고가 크게 형성되는 경 향이 뚜렷하게 나타나고 있다(Kang et al., 2014).

\section{3 시차특성}

대형태풍에 의한 해일특성을 고찰하기 위하여 먼저 1951 년 이후 한반도에 영향을 미친 태풍 191개를 분석한 연구 (Kang, 2015)에 최근 자료를 추가하여 전절에 언급한 조시 및 조석-해일 비선형 특성의 국내 현황을 살펴보았다. 이들 태 풍에 의한 최대해일고 발생당시의 조시(tidal phase)를 낙조, 저 조, 창조, 고조로 구분한 후 태풍의 최근접거리 통과시점으로 부터 최대해일고 발생시점까지의 시차(time lag)를 Fig. 1에 (a) 서해안(인천/안흥/군산), (b) 남서해안(목포/완도), (c) 남해 안(여수/통영/부산) 등 3 개 해역별로 도시하였다. 남해안을 제 외한 여타 해역에서 최대해일고가 저조시에 발생한 사례가 $60 \%$ 정도로 압도적으로 많음을 볼 수 있는데, 이는 전절에 서 언급한 바와 같이 조석변조해일의 조석-해일 비선형성과 일치하는 현상이다. 또한 남해안에서는 대부분 $0 \sim 1$ 시간 정도 의 미미한 음(-)의 시차가 발생하고 있는 반면 서해안 지역 에서는 3 시간 이상의 양 $(+)$ 의 시차로 나타나고 있는데, 이 역 시 서해안 특유의 시차특성과 일치하는 양상이다. 남서해안

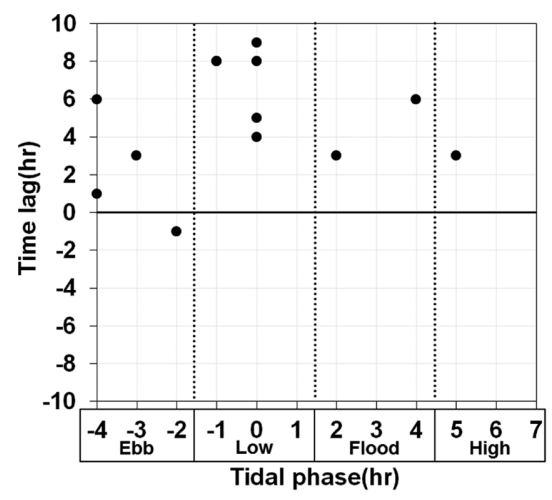

(a) Western coast

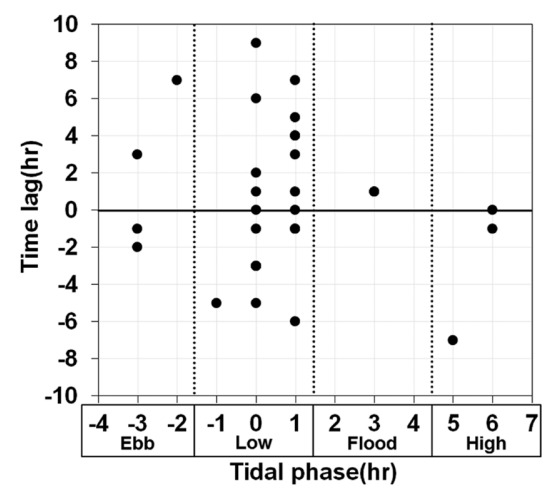

(b) Southwestern coast

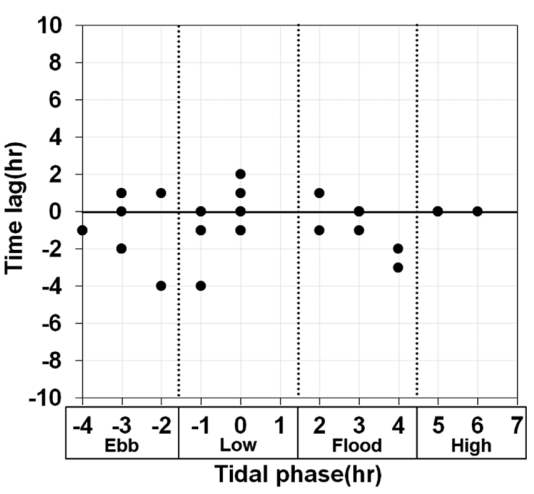

(c) Southern coast

Fig. 1. Temporal characteristics of maximum surge. 
Table 1. Maximum surge height and parameters of major typhoons

\begin{tabular}{|c|c|c|c|c|c|}
\hline Typhoon & Site & Max. surge $(\mathrm{cm})$ & Distance $(\mathrm{km})$ & Atm. pressure $(\mathrm{hPa})$ & Track speed $(\mathrm{km} / \mathrm{h})$ \\
\hline \multirow{4}{*}{$\begin{array}{l}\text { WINNIE } \\
\text { (9713) }\end{array}$} & IC & 53 & 540 & 995 & 56 \\
\hline & $\mathrm{AH}$ & 68 & 565 & 995 & 56 \\
\hline & GS & 44 & 627 & 996 & 28 \\
\hline & MP & 40 & 689 & 996 & 37 \\
\hline \multirow{4}{*}{$\begin{array}{l}\text { OLGA } \\
(9907)\end{array}$} & IC & 83 & 18 & 985 & 59 \\
\hline & $\mathrm{AH}$ & 34 & 5 & 983 & 47 \\
\hline & GS & 56 & 46 & 980 & 47 \\
\hline & MP & 36 & 45 & 975 & 26 \\
\hline \multirow{4}{*}{$\begin{array}{l}\text { PRAP- } \\
\text { IROON } \\
(0012)\end{array}$} & IC & 118 & 105 & 978 & 43 \\
\hline & $\mathrm{AH}$ & 73 & 120 & 975 & 43 \\
\hline & GS & 72 & 189 & 970 & 38 \\
\hline & MP & 48 & 216 & 965 & 39 \\
\hline \multirow{4}{*}{$\begin{array}{c}\text { KOMPASU } \\
(1007)\end{array}$} & IC & 75 & 23 & 985 & 45 \\
\hline & $\mathrm{AH}$ & 69 & 51 & 985 & 45 \\
\hline & GS & 42 & 136 & 979 & 41 \\
\hline & MP & 30 & 136 & 973 & 41 \\
\hline \multirow{4}{*}{$\begin{array}{c}\text { MUIFA } \\
\text { (1109) }\end{array}$} & IC & 83 & 237 & 983 & 23 \\
\hline & $\mathrm{AH}$ & 68 & 214 & 980 & 30 \\
\hline & GS & 51 & 270 & 980 & 30 \\
\hline & MP & 36 & 229 & 975 & 26 \\
\hline \multirow{4}{*}{$\begin{array}{c}\text { BOLAVEN } \\
(1215)\end{array}$} & $\mathrm{IC}$ & 140 & 173 & 970 & 39 \\
\hline & $\mathrm{AH}$ & 101 & 122 & 963 & 34 \\
\hline & GS & 106 & 155 & 963 & 34 \\
\hline & MP & 59 & 115 & 960 & 34 \\
\hline
\end{tabular}

의 경우 남해안과 서해안의 특성을 모두 내포하고 있어 매우 폭넓은 시차를 보이고 있다.

이와 같이 국내연안에서 발생하는 태풍해일은 해역별로 독 특한 특성을 보이고 있는데, 이는 조석-해일 비선형특성, 그리 고 태풍의 경로 및 이동특성 등과 무관치 않다. 강력한 태풍 이 빠른 속도로 인접해 통과할 경우 조석변조해일특성이 작 용할 여유도 없이 해당영역 인근에 직접적인 영향을 초래하 게 되면서 최대해일고가 저조시점과 무관하게 형성될 수 있 으며, 영역 밖에서 발생된 태풍해일이 전파되어 온 성분이 크 게 작용하는 경우 역시 최대해일고 발생시점은 해당영역의 조 시와는 무관하게 형성된다. 그러나 서해안과 남서해안에서 발 생하는 상당수의 태풍해일사상은 조석-해일 비선형특성에 의 해 저조시 최대해일고가 발생하는 경향이 있는데, 이러한 서 해안 태풍해일특성에 대하여 다음 장에서 구체적으로 살펴본다.

\section{3. 사례분석을 통한 서해안 태풍해일특성}

\section{1 태풍사상 선정}

태풍영향기간 동안 관측된 최대해일고가 $50 \mathrm{~cm}$ 를 초과하는 태풍을 선별하여 수행된 연구(Kang, 2015)에서 제시된 바와 같이 인천을 비롯한 서해안에 위치한 조위관측소에서 관측된 $50 \mathrm{~cm}$ 이상의 해일고를 유발하는 태풍은 거의 대부분 서해안 으로 진입한 태풍에 의해서이다. 서론에서 밝혔듯이 서해안으 로 진입하는 태풍은 미래기후환경에서는 대형화되는 추세일
것으로 예측되고 있다. 이러한 서해안으로 진입하는 대형태풍 에 대한 태풍-해일특성을 살펴보기 위해 해당 연구에서 선별 한 태풍 중 서해안 지역 2개소 이상에서 해일고가 $50 \mathrm{~cm}$ 이 상으로 컸던 WINNIE(9713), OLGA(9907), PRAPIROON (0012), KOMPASU(1007), MUIFA(1109), BOLAVEN(1215) 등 서해안경로를 취한 대표적인 대형태풍 6개를 분석대상으

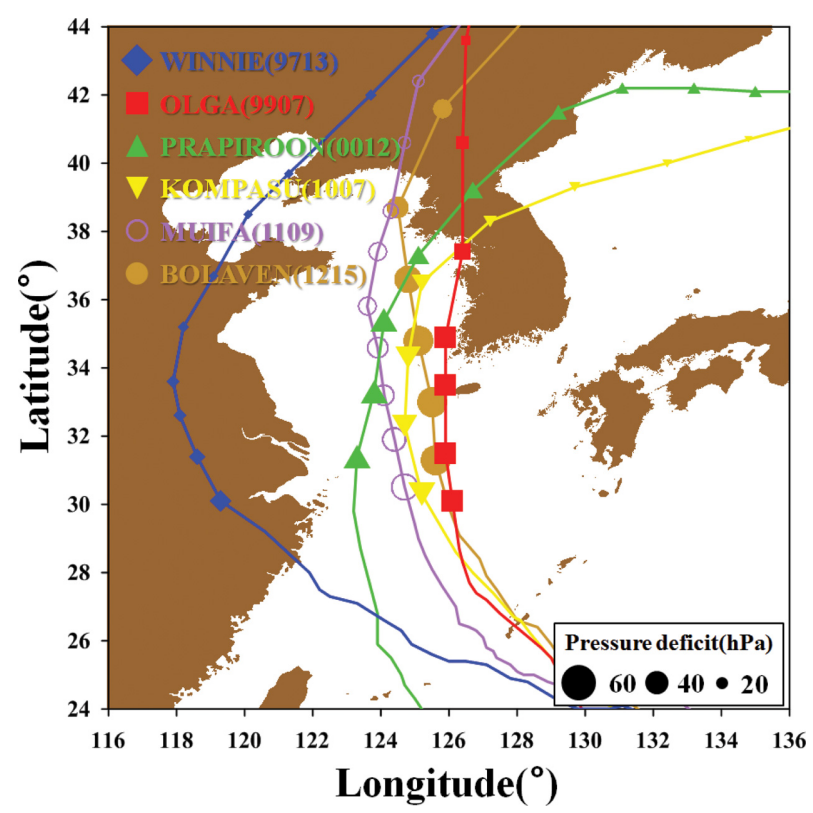

Fig. 2. Typhoon tracks. 
로 선정하였다. 인천(IC), 안흥(AH), 군산(GS), 목포(MP) 등 4 개 서해안 지역에서 관측된 태풍해일의 최대해일고와 최단 거리, 최단거리 당시 기압 및 이동속도 등을 Table 1에 제시 하였으며 이들 태풍의 경로를 Fig. 2에 도시하였다. 여타 5개 태풍이 서해안에 인접하여 통과한 것에 비해 태풍 WINNIE (9713)의 경우 중국에 상륙하여 세력이 약해진 상태로 멀리 이격하여 통과하였지만 우리나라 서해안에 이례적으로 적지 않은 영향을 미친 바 있다.

\section{2 태풍해일유형 구분}

$\operatorname{Kang}(2015)$ 의 연구에서 대형태풍에 의해 발생되는 해일양 상은 해일고의 첨두치가 뚜렷한 첨두형(steep type)과 첨두부 근의 해일고 변화가 비교적 완만한 지속형(mild type) 등의 두 가지로 구분한 바 있다. 태풍의 이동속도가 $40 \mathrm{~km} / \mathrm{h}$ 이상 인 경우 첨두형, 미만인 경우 지속형이 형성되는 경향이 있 고, 첨두형의 경우 태풍 중심이 해당 조위관측소를 $200 \mathrm{~km}$ 이내로 이격하여 통과할 때 형성되는 반면 지속형은 이격거 리에 무관하게 형성되는 양상을 보이고 있다. 이에 따르면 남 해안에 큰 피해를 발생시킨 대표적인 두 개의 태풍인 RUSA (0215)와 MAEMI(0314)가 각각 지속형과 첨두형으로 구분되 는 특성을 보이고 있음을 제시한 바 있다. 본 연구에서도 선 정된 6 개 대표태풍의 해일사상에 대하여 유사한 기준으로 해 일발생양상을 재구분하였다. 즉, 최대해일고 시점을 포함하여 최대해일고 파형이 유지되는 시간이 조석주기인 12 시간에 미 달하여 조석상황과 관계없이 해일 발생이 급격한 상승 및 하 강의 양상을 보이는 경우를 첨두형(Fig. 3(a)), 최대해일고 파 형이 유지되는 시간이 조석주기를 초과하는 시간 동안 이루 어져 완만한 상승 및 하강의 양상을 보이지만 최대해일고는

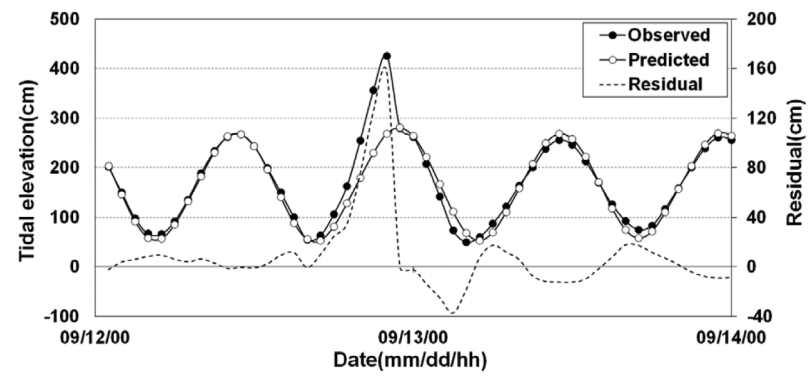

(a) S-type : MAEMI(0314) at Tongyoung

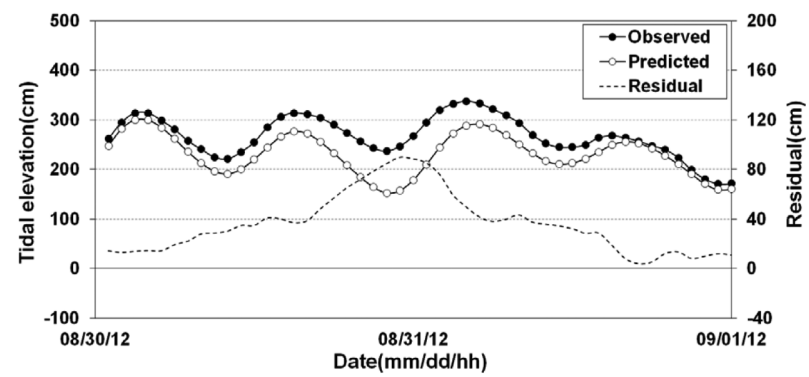

(b) M-type : RUSA(0215) at Wando

Fig. 3. Typical surge types (Kang, 2015).
바람의 영향이 가장 크게 나타나는 저조시에 주로 발생하는 조석변조해일의 경향을 보이는 지속형(Fig. 3(b))으로 구분하 였다.

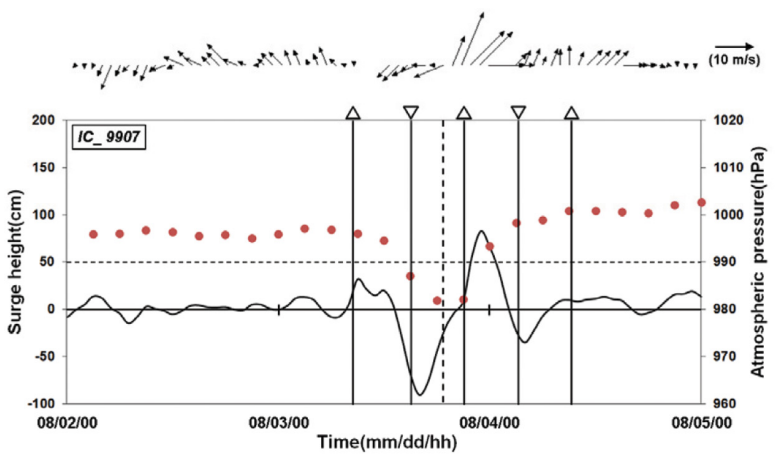

(a) OLGA(9907) at Incheon

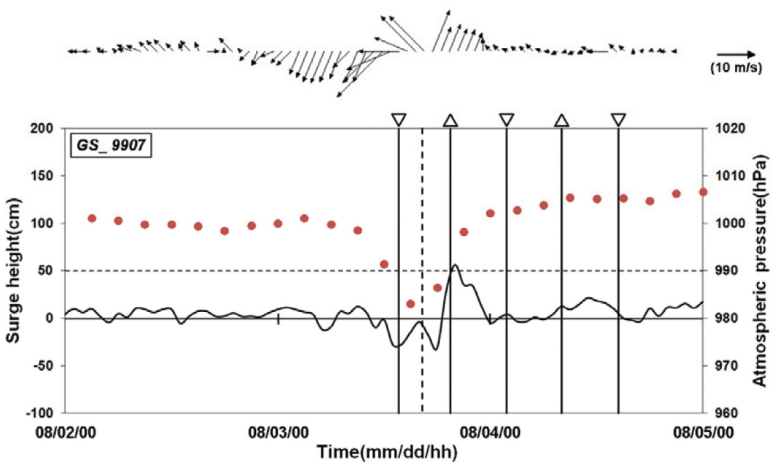

(b) OLGA(9907) at Gunsan

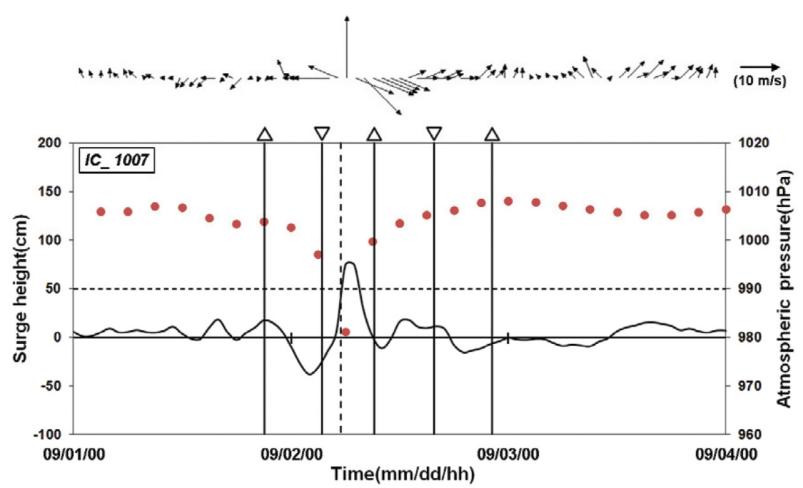

(c) KOMPAS(1007) at Incheon

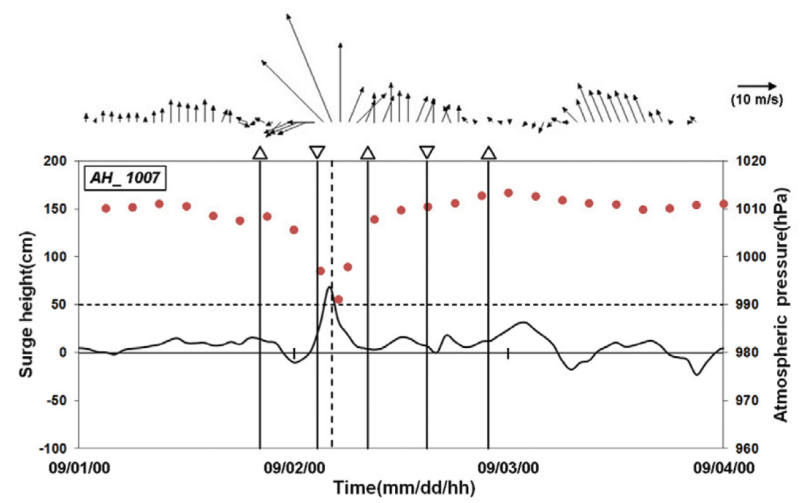

(d) KOMPAS(1007) at Anheung

Fig. 4. Time series of typical steep surge type at Western coast. 


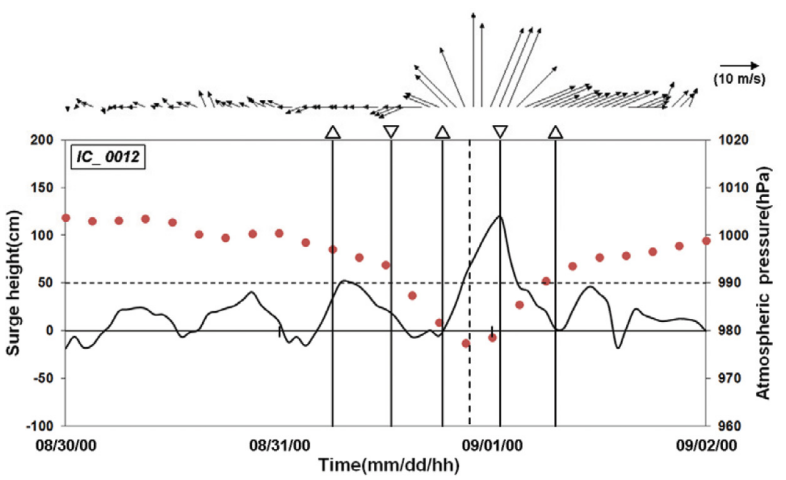

(a) PRAPIROON(0012) at Incheon

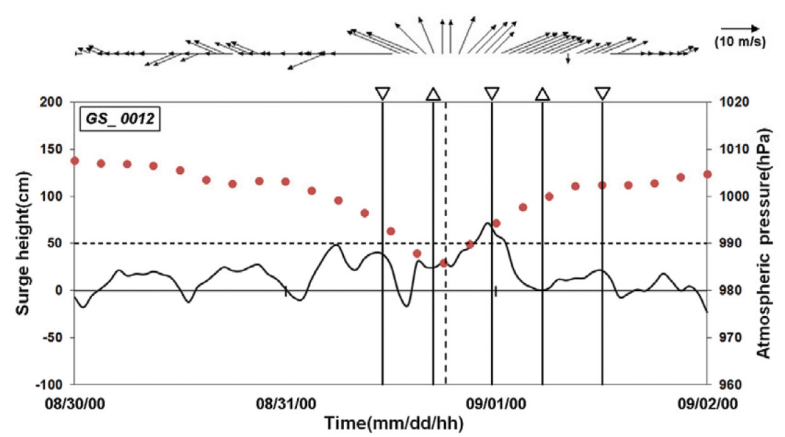

(b) PRAPIROON(0012) at Gunsan

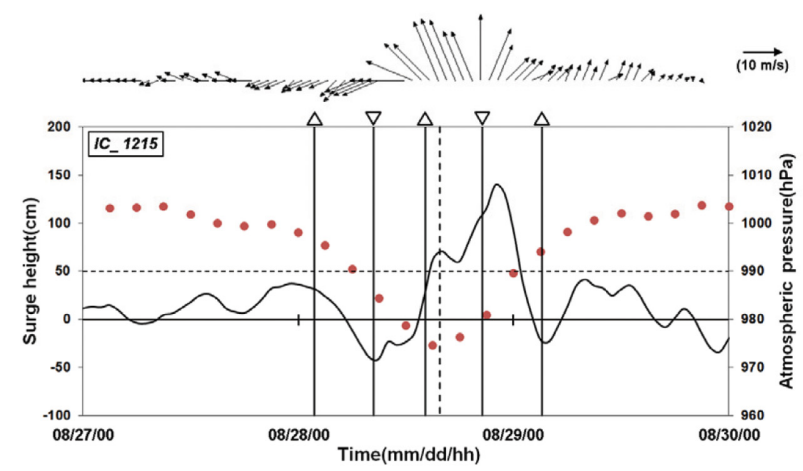

(c) BOLAVEN(1215) at Incheon

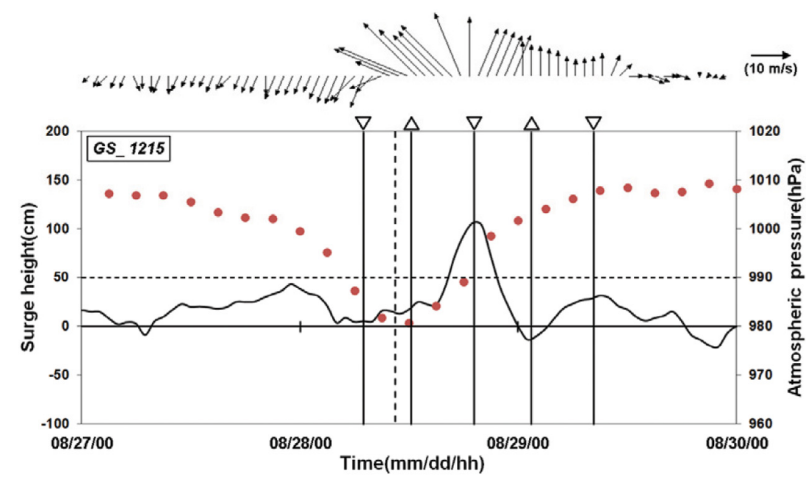

(d) BOLAVEN(1215) at Gunsan

Fig. 5. Time series of typical mild surge type at Western coast.

Table 1의 이격거리와 이동속도를 감안하면 서해안에 인접 하여 매우 빠른 속도로 통과한 태풍인 OLGA(9907)에 의한 인천, 안흥, 군산 등에서의 해일사상과 황해로 진입한 후 인

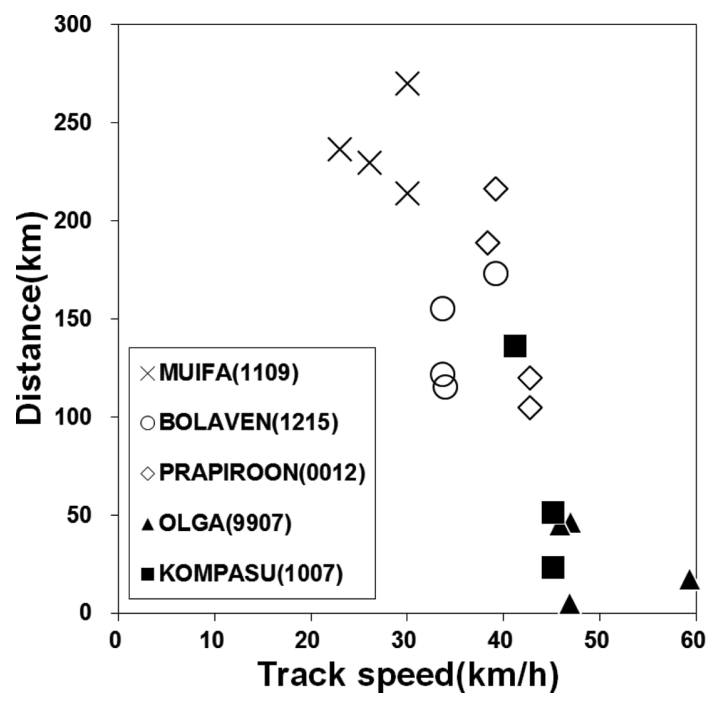

Fig. 6. Scatter diagram with respect to track speed and distance.

천 북단에 상륙한 태풍인 $\mathrm{KOMPAS}(1007)$ 에 의한 인천, 안 흥 등의 해일사상이 첨두형으로 구분될 수 있다. 고조 $(\triangle) /$ 저 조 $(\nabla)$ 시점 및 점선으로 표시한 태풍의 최근접시점과 함께 실제 해일파형을 도시한 Fig. 4를 보면 상기한 첨두형의 정 의와 같이 최대해일고 발생시점의 파형이 조석주기인 12 시간 에 미달하여 급격한 승강을 보이고 있음을 확인할 수 있다. 서해안 통과 태풍 중 첨두형은 상기 태풍을 제외하고는 찾아 보기 어려우며 이외의 여타 태풍해일사상은 모두 지속형으로 구분될 수 있다. 대표적인 대형태풍의 지속형 해일파형을 Fig. 5 에 도시하였다. 지속형의 경우 해일발생이 완만한 변화와 함 께 저조시에 최대해일고가 형성되는 특성을 보이고 있다.

한반도에서 멀리 이격하여 통과한 태풍 WINNIE(9713)를 제외한 5 개 대형태풍의 서해안 4 개 지점에서의 태풍통과시 최 근접거리 및 당시의 이동속도를 Fig. 6에 제시하였다. 첨두형 으로 구분된 OLGA(9907)와 KOMPAS(1007)의 경우 $40 \mathrm{~km} /$ $\mathrm{h}$ 를 초과하는 빠른 이동속도와 대부분 $100 \mathrm{~km}$ 이내의 최근 접거리를 보이고 있으나 나머지 지속형 태풍들은 첨두형과 상 반된 성향을 보이고 있다. 즉, 첨두형 태풍해일은 근접하여 빠 른 속도로 통과하는 태풍에 의해 형성되며 해일발생이 통과 시점에 맞춰 짧은 시간 동안 이루어지는 반면, 지속형의 경 우 멀리 떨어져서 느린 속도로 통과함에 따라 해일발생 역시 완만하게 형성되며 식(1)에 제시된 원리에 따라 수심이 얕아 지는 저조시에 맞춰 해일고가 증폭되는 성향을 보이게 된다.

\section{3 서해안 태풍해일유형 특성}

전술한 6개 대표태풍을 첨두형과 지속형의 유형별로 구분 하여 서해안 지역에 미친 해일특성에 대한 분석을 시행하였 다. 이 태풍들 중 WINNIE(9713)와 MUIFA(1109)는 지속형 으로 구분되지만, 영역 밖에서 전파된 해일의 영향이 크게 나 타나는 특성을 보이기에 지속형과는 별도로 전파형 태풍으로 분류하여 소개한다. 


\section{1) 첨두형}

서해안에서 관측된 첨두형으로 태풍 OLGA(9907)와 KOMPASU(1007)가 대표적인데 두 태풍의 경로를 보면 매우 유사하게 서해안을 인접하여 통과하고 있으며 통과속도도 매 우 빠른 편이어서 주로 저조시에 최대해일고가 발생하는 지 속형과는 달리 Fig. 4에 보인 바와 같이 점선으로 표기된 태 풍통과 직후 수 시간 이내 짧은 시차후에 조시와 무관하게 최 대해일고가 발생하고 있음을 볼 수 있다.

태풍 OLGA(9907)의 경우 인천과 군산에서 저조와 고조 중간인 창조시점에 태풍이 통과하였으며 최대해일고는 기압 강하가 최대가 되는 태풍통과시점에서 3 6시간 경과한 고조 직후 발생하고 있다. 그림 상단에 함께 도시한 풍속정보(위 쪽을 향하는 화살표 방향이 북향인 남풍을 의미함)를 참조하 면 2.3절에 소개한 시차특성에 부합하는 현상이 나타나고 있 는데, 즉 태풍 통과시점을 전후로 육풍(풍향의 서쪽 성분)에 서 해풍(풍향의 동쪽 성분)으로 전환되고 있으며 최대해일고 는 해풍성분이 극대화되는 시점에서 발생하고 있다. 이어지 는 저조시 해일고는 후술될 지속형과 달리 미미한 수준으로 나타나고 있지만 태풍 통과직전 인천에서는 육풍이 최대가 되 는 동시에 바람에 의한 해일고가 극대화되는 저조가 겹쳐 음 의 해일이 매우 두드러지게 나타나고 있음은 특기할 만하다. 인천과 안흥에서 저조 직후 태풍이 통과한 $\mathrm{KOMPAS}(1007)$ 역시 태풍통과시점에 풍향이 바뀌고 있음을 볼 수 있다. 그 러나 최대해일고 발생은 인천의 경우 태풍통과 한시간여 경 과후에 발생하고 있으며 안흥의 경우에는 거의 동시에 발생 하고 있는 등 이동속도가 빠른 첨두형 태풍의 경우 시차특성 이 크게 나타나지는 않고 있다.

\section{2) 지속형}

서해안을 근접하여 빠른 속도로 통과한 대표적인 두 개의 첨두형 태풍을 제외하고는 대부분의 서해안 통과 태풍은 지 속형으로 구분된다. $\operatorname{Kang}(2015)$ 의 연구에서도 목포에 영향을 미친 $50 \mathrm{~cm}$ 이상의 해일고를 유발한 태풍 18 개 중 16 개가 지속형으로 구분되고 있으며 서해안 통과의 이격거리가 멀거 나 세력이 약해 해일고가 $50 \mathrm{~cm}$ 미만으로 작게 형성된 태풍 들은 거의 대부분 지속형으로 구분된다. 해일고가 작게 형성 된 태풍들은 제외하고 서해안 전역에 걸쳐 $50 \mathrm{~cm}$ 이상의 해 일고를 발생시킨 태풍으로 PRAPIROON(0012)과 BOLAVEN (1215) 등이 대표적인 지속형이며 Fig. 5에 이들의 해일파형 을 도시하였는데 첨두형과는 달리 이들 지속형에서는 저조시 높은 해일고가 형성되고 있다. 특히 BOLAVEN(1215)은 중 심기압이 960 여 $\mathrm{hPa}$ 로 서해안 통과태풍 중 가장 강한 태풍으 로서 첨두형 태풍에 비해 먼 이격거리와 느린 이동속도를 보 여 조석변조해일 현상에 의해 저조시 극대화된 최대해일고를 보이고 있다. BOLAVEN(1215)의 통과시점은 고조 무렵이고 PRAPIROON(0012)은 고조 직후에 통과함에 따라 시차현상 에 의해 이어지는 저조시 극대화된 최대해일고를 보이고 있
다. 이에 따라 BOLAVEN(1215)은 인천, 안흥, 군산 등에서 $100 \mathrm{~cm}$ 를 초과하는 해일고를 초래하여 서해안 통과 태풍 중 최대해일고를 유발한 태풍이고 PRAPIROON(0012) 역시 인 천에서 $100 \mathrm{~cm}$ 를 초과하는 해일고를 보이는 등 양 태풍은 서 해안 지역에서 역대 최대의 해일고를 보인 태풍이다. 이들은 고조무렵에 통과하여 시차특성에 따라 이어지는 저조시 최대 해일고가 발생하는 지속형 태풍이라는 해일고가 극대화 되기 위한 공통적인 조건을 갖추고 있다.

Fig. 1에서도 보였듯이 목포와 완도를 포함하여 서해안 지역 에서는 수심이 얕고 조석이 지배적이어서 조석-해일 비선형성 에 의해 저조시 최대해일고가 나타나는 조석변조해일의 빈도 가 높다. 중국의 Zhe-Min 해역을 대상으로 수치모의를 통해 저 조시와 고조시 발생되는 해일고를 계산한 결과(Wuxi et al., 2018)를 보더라도 저조시는 $30 \%$ 정도 해일고가 크게 나타나 는 반면 고조시엔 $15 \%$ 정도 해일고가 감소하는 것으로 나타 났다. 따라서 태풍의 이동속도와 이격거리에 따라 분류된 태 풍해일유형 뿐 아니라 태풍이 통과한 시점의 조석상황 역시 발 생되는 해일고 크기와 무관치 않다. 저조시에 주로 최대해일 고가 발생하는 경향이 있는 지속형 태풍의 경우 극대화된 해 일고를 보이는 반면 최대해일고 발생이 고조시에도 발생가능 한 첨두형에서는 고조시 발생한 해일고는 저조시 발생할 경우 에 비해 상당히 작게 형성될 수 있는 것이다. 이와 같이 조석 이 지배적인 서해안에서는 태풍해일의 유형과 조석-해일 비선 형특성 및 조시 등에 따라 최대해일고 크기가 달라질 수 있다.

\section{3) 전파형}

한편 영역 밖에서 전파되어온 해일의 크기를 가늠하기 위 해 황해를 $30 \mathrm{~km} / \mathrm{h}$ 이하의 매우 느린 이동속도로 관통한 태 풍인 MUIFA(1109)에 대하여 서해안의 군산, 안흥, 인천 지 역에서 관측된 해일파의 파형을 Fig. 7에 제시하였다. 3 개 지 점에서 MUIFA(1109)의 최근접시점을 수직점선으로 표시하 였는데, 이 시점의 3 4일 이전부터 일정한 시차를 두고 주기 적이면서 점차 증폭되는 해일파형이 군산, 안흥, 인천의 순차 적으로 평행이동한 형태로 유사하게 형성(점선으로 나타낸 사 각형 내부 참조)되고 있다. 이후 태풍이 접근함에 따라 기압

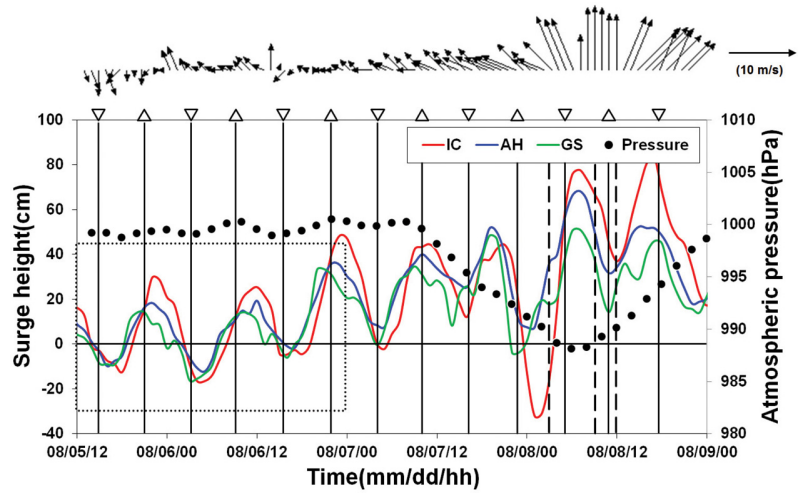

Fig. 7. Surge time series of typhoon MUIFA (1109). 
과 풍속이 강해져 영역내 해일고가 성장하면서 세 개 지역의 해일고 발생양상은 점차 서로간의 유사성을 잃고 있음을 볼 수 있다. 한편 이동속도가 매우 느린 MUIFA(1109)와는 달 리 이동속도가 매우 빠른 OLGA(9907) 및 KOMPASU(1007) 와 같은 첨두형의 경우 Fig. 4에 보인 바와 같이 태풍 도착 전 뚜렷한 해일파형이 보이지 않는다. 따라서 태풍이 도달하 기 전에는 해당 지역에서 태풍의 직접적 영향이 미미한 기상 상태(Fig. 7에 나타낸 인천에서의 풍속과 기압 참조)임에도 불 구하고 MUIFA(1109)에서와 같이 유사하게 형성된 파형의 근 간은 태풍보다 먼저 전파되어 온 해일파라 할 수 있다. 이렇 게 영역내의 조석상황과 무관하게 지속적으로 전파되어 온 해 일파가 태풍 통과에 맞춰 영역내에서 발생하는 해일에 중첩 되는 상황에서, 전파되어 온 해일파가 영역내에서 발생된 해 일파에 비해 여전히 우세할 경우 최대해일고 역시 전파형의 원래 주기에 맞춰 형성되는 경향을 보이게 되므로 지속형 태 풍임에도 불구하고 최대해일고 발생이 저조시점과 무관하게 될 수 있다.

이렇게 전파형 해일이 가장 극명하게 드러나는 경우는 태 풍 WINNIE(9713)로서 Fig. 8에 제시되었듯이 조석주기와 비 슷한 주기로 해일파형이 형성되고 있다. 해일파형이 조석주 기와 비슷한 주기로 형성되고 있음은 외부에서 형성된 해일

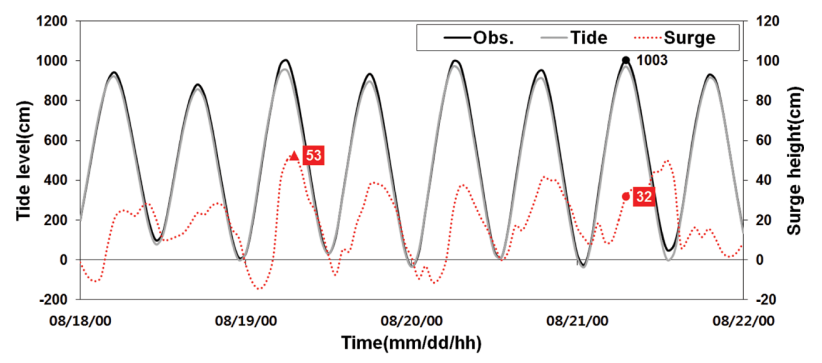

(a) Incheon

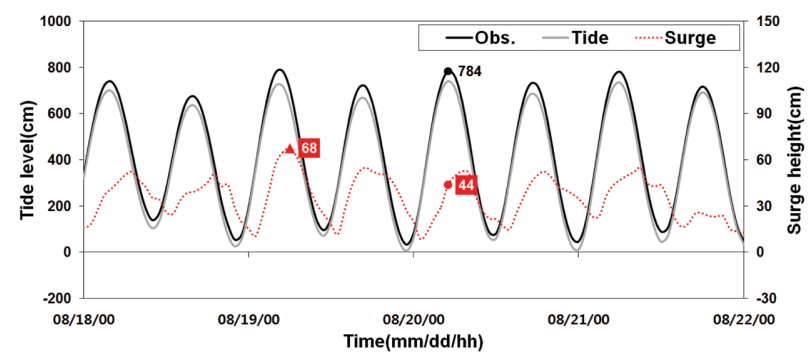

(b) Anheung

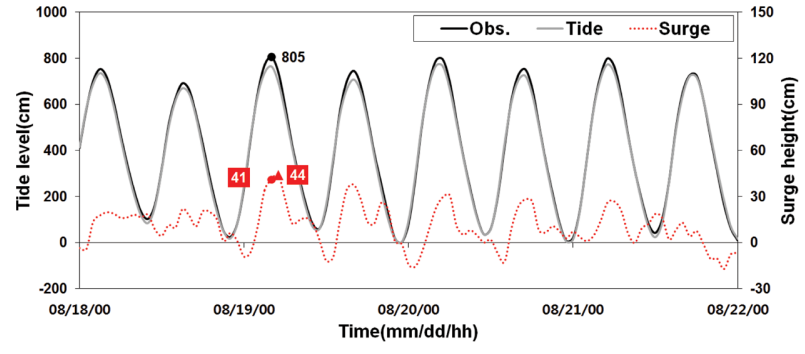

(c) Gunsan

Fig. 8. Time series of tidal levels with surge during the typhoon WINNIE (9713).
파 역시 생성될 당시 해역의 조석-해일 비선형 특성에 기인 한 것으로 추정된다. 그러나 영역내에서 형성된 해일파는 조 석변조해일의 기작으로 저조시 높은 해일고가 형성되는 반면, 영역 밖에서 전파되어 오는 해일의 경우 전파되어 온 시점과 해당 지점의 조시는 무관하므로 저조 발생이 아닌 경우가 많 다. 따라서 대조기 고조시에 영역 밖에서 전파되어 오는 해 일의 규모가 클 경우 고조에도 최대해일고가 겹치는 상황이 가능하며 태풍 WINNIE(9713)가 이러한 대표적 사례라 할 수 있다. 태풍 통과시점인 8월 20일 전후 백중사리시기에 매 우 높은 고조(천문조)가 예측되었었고 여기에 태풍에 의한 반 복적인 해일파의 첨두치가 고조시와 일치함에 따라 인천을 비 롯한 서해안 전역에서 기왕최고극조위가 형성된 바 있으며, 이 내용은 다음 장에 구체적으로 기술하였다.

Moon et al.(2003)은 태풍 WINNIE(9713)가 Fig. 2에 보 인 바와 같이 황해를 우회하여 진행함에 따라 우리나라 서해 안에서 태풍의 직접적인 영향이 매우 적었음에도 $50 \mathrm{~cm}$ 이 상의 해일고가 기록된 이유에 대해서 분석한 바 있다. 즉, 태 풍에 의해 발생된 해일파가 황해로 유입된 전파형 해일임을 수치실험을 통해 확인하였으며 황해의 공진주기에 맞춰 해일 파가 증폭된 것이란 분석이다. 태풍 WINNIE(9713)와 MUIFA (1109) 등 전파형 태풍 외에도 Fig. 5에 제시된 PRAPIROON (0012)과 같이 상당수 지속형 태풍에서 해일파가 도착하기 전 에 영역내 기상과 상관없이 주기적인 해일파형이 검출되는 것 으로 보아 외해역에서 발생된 해일파가 황해로 유입되어 영 향을 미치는 경우가 적지 않을 것으로 추정된다. 이렇게 외 부에서 전파되어 유입된 해일의 경우 규모는 크지 않지만 발 생빈도가 잦고 고조시 발생이 가능하므로 대조기 고조와 조 우할 경우 범람 위험도가 가장 높은 유형이다.

\section{4. 고극조위 형성}

\section{1 연고극조위 발생 양상}

조석현상(천문조)에 따라 대조기(사리)마다 고조시 해면고 가 보름 주기로 매우 높게 형성된다. 음력 7월 15일인 백중 을 전후한 사리 때 해면고가 가장 높다고 해서 백중사리라 하 는데, 이는 장주기조인 연주조( $\mathrm{Sa}$ 분조)의 영향으로 하절기에 평균해수면이 가장 높게 형성될 때 사리가 겹쳐 연최고해면 고가 이 시기에 주로 형성됨에 연유한 것이다. 이에 따라 해 당연도의 최고조위를 의미하는 연고극조위(annual highest high water level; AHHWL)가 양력 7월 10월의 하절기 대조 기에 형성되고 있음을 흔히 볼 수 있다. 게다가 이 시기는 태 풍에 의한 해일발생이 겹치는 시기이므로 연고극조위 발생이 집중되고 있다.

우리나라 주요 조위관측소 지점에서 기록된 연고극조위 순 위와 태풍의 영향여부를 조사하여 대표적으로 인천조위관측 소의 결과를 Table 2에 제시하였다. 해당 지점에서 1 순위에 해당하는 기왕최고극조위(record highest high water level; 
Table 2. Top 10 AHHWL at Incheon

\begin{tabular}{|c|c|c|c|c|c|}
\hline Rank & "Date (yy/mm/dd) & "AHHWL (cm) & Tide $(\mathrm{cm})$ & "Surge $(\mathrm{cm})$ & Typhoon \\
\hline 1 & $97 / 08 / 21$ & 1003 & 971 & 32 & WINNIE \\
\hline 2 & $13 / 07 / 24$ & 987 & 958 & 29 & \\
\hline 3 & 02/09/08 & 981 & 947 & 34 & \\
\hline 4 & $03 / 10 / 27$ & 980 & 946 & 34 & \\
\hline 5 & $07 / 10 / 28$ & 980 & 948 & 32 & \\
\hline 6 & $15 / 09 / 30$ & 978 & 952 & 26 & \\
\hline 7 & $01 / 08 / 21$ & 976 & 939 & 38 & \\
\hline 8 & $00 / 08 / 31$ & 976 & 942 & 34 & PRAPIROON \\
\hline 9 & $10 / 08 / 13$ & 974 & 949 & 25 & DIANMU \\
\hline 10 & $84 / 08 / 29$ & 970 & 955 & 15 & \\
\hline
\end{tabular}

Table 3. Record highest high water levels (RHHWL)

\begin{tabular}{lcccccc}
\hline \hline Site & Date $(\mathrm{yy} / \mathrm{mm} / \mathrm{dd})$ & RHHWL $(\mathrm{cm})$ & Tide $(\mathrm{cm})$ & Surge $(\mathrm{cm})$ & Typhoon & No. of typhoons \\
\hline IC & $97 / 08 / 21$ & 1003 & 971 & 32 & WINNIE & $3 / 10$ \\
AH & $97 / 08 / 20$ & 784 & 740 & 44 & WINNIE & $2 / 10$ \\
GS & $97 / 08 / 19$ & 805 & 764 & 41 & WINNIE & $2 / 10$ \\
MP & $04 / 07 / 04$ & 544 & 521 & 23 & MINDULLE & $3 / 10$ \\
WD & $10 / 08 / 10$ & 442 & 421 & 21 & DIANMU & $2 / 10$ \\
YS & $01 / 09 / 18$ & 409 & 399 & 10 & - & $2 / 10$ \\
TY & $03 / 09 / 12$ & 426 & 269 & 157 & MAEMI & $3 / 10$ \\
BS & $03 / 09 / 12$ & 211 & 139 & 72 & MAEMI & $5 / 10$ \\
SC & $02 / 09 / 01$ & 100 & 46 & 54 & RUSA & $7 / 10$ \\
\hline
\end{tabular}

RHHWL) D.L.1,003 cm는 태풍 WINNIE(9713) 시기에 발 생하였는데, 그 당시 인천의 약최고고조위인 D.L.927 cm를 훨 씬 초과한 D.L.971 cm의 고조위가 예측된 바 있고 여기에 태 풍해일고 $32 \mathrm{~cm}$ 가 추가되어 형성된 바 있다(Fig. 8 참조). 10 위 내에 포함된 사상 중 3 가지 경우만 태풍영향시기에 발생 하였을 뿐 나머지 경우는 약최고고조위를 대부분 $20 \mathrm{~cm}$ 이 상 초과하는 높은 조위조건에 비태풍 해일고가 겹쳐 발생하 는 양상을 보이고 있다.

우리나라 주요 조위관측소인 인천(IC), 안흥(AH), 군산 (GS), 목포(MP), 완도(WD), 여수(YS), 통영(TY), 부산(BS), 속초(SC) 등 9 개소에서 상위 10 위까지의 연고극조위 중 기 왕최고극조위 발생사상만을 발췌하여 10 위 내에 태풍영향 사 상의 횟수(No. of typhoons)와 함께 Table 3에 제시하였다. 부산 및 속초와 같이 조차가 크지 않은 곳에서는 연고극조위 형성에 태풍이 관여한 사상이 5 7개 정도이고 기왕최고극조 위 발생 당시 기여한 해일고의 크기도 작지 않아 태풍에 의 한 해일의 기여도가 높게 나타나고 있다. 반면 조석이 지배 적인 서해안과 남서해안에서는 태풍이 관여한 사상이 2 3개 정도에 불과하여 태풍과 무관하게 연고극조위가 형성되는 경 우가 적지 않으며, 여수의 경우 기왕최고극조위가 비태풍 시 기에 형성되고 있기도 하다. 특히 서해안에서는 기왕최고극 조위를 기록한 바 있는 WINNIE(9713)를 제외하면 기검토된 나머지 5 개의 서해안 대형태풍 중 PRAPIROON(0012)만이 10 위 안에 포함되어 있으며 연고극조위 형성에 기여한 해일 고 크기 역시 대부분 $50 \mathrm{~cm}$ 에도 미달하고 있다. 이는 기록된 기간이 40 50년 정도라 50년 이하의 재현기간을 갖는 극치
해면고는 태풍의 영향 없이도 발생할 수 있다는 연구(Kang and $\mathrm{Kim}, 2018$ )와도 일맥상통하는 결과로서 50년 빈도의 극 치해면고는 태풍의 영향이 포함된 경우라도 높은 천문조 조 건에 소규모 해일고가 겹쳐진 상황에서 발생하고 있음을 확 인할 수 있다.

PRAPIROON(0012)의 경우 Fig. 5에 보인 바와 같이 최대 해일고는 인천과 군산에서 저조시에 발생하였지만 $50 \mathrm{~cm}$ 에 미달하는 해일파의 여파가 백중사리 시기에 극대화된 천문조 에 부가되어 군산에서는 역대 2 위의 연고극조위가 발생하는 등 서해안 전역에서 높은 고극조위가 기록된 바 있다. 이와 같이 서해안의 경우 50 년 이하의 극치해면고가 형성되는 경 우는 대조기 고조시에 크지 않은 해일고가 겹치는 상황이 대 부분이다. Fig. 8에 보인 인천(IC), 안흥( $\mathrm{AH})$, 군산(GS) 등 서해안 대부분 지역에서 전파형인 태풍 WINNIE(9713)로 인 해 $50 \mathrm{~cm}$ 에 미달하는 해일고가 백중사리의 높은 고조시에 동 반되어 기왕최고극조위가 기록된 것 역시 극치해면 발생에 있 어 조석지배적인 서해안의 특성을 시사하는 일례이다.

\section{2 고극조위 발생패턴}

3장에서 서해안으로 진입한 태풍 및 그로 인한 해일파로 인 해 서해안 각 지역에서 형성되는 태풍해일유형에 따른 특성 을 살펴보았다. 이러한 태풍해일유형을 토대로 고극조위가 발 생하는 패턴을 구분하면 다음과 같다.

\section{1) 첨두형}

첨두형 태풍해일은 이동속도가 빠르며 대상지역을 근접하 
여 통과하는 태풍에 의해 주로 발생하는 해일이지만 과거자 료를 분석해 보면 대형태풍이 빠른 속도로 근접하여 통과하 는 경우는 흔치 않기에 이 유형 자체가 매우 드물게 발생한 다. 그러나 서해안으로 유입된 태풍은 위도가 높아질수록 이 동속도가 빨라지는 경향이 있으므로 태풍의 강도가 유지된 상 태에서 근접하여 통과할 경우 목포나 군산에 비해 인천에서 와 같이 서해안의 고위도일수록 첨두형 발생 가능성은 높아 진다. 이 유형은 바람에 비해 기압에 의한 해일고가 큰 편이 기에 조석변조해일이 두드러지지 않을 뿐 아니라 빠른 이동 속도 때문에 최대해일고 발생시점이 조시와 무관하게 형성된 다. 따라서 저조에 극대화되는 해일에 비해 해일고 자체는 작 게 형성되겠지만 최대해일고가 고조시에도 발생할 수 있으므 로 매우 작은 확률로서 서해안에 막대한 범람피해를 초래할 수도 있는 유형이다. 즉, 장차 서해안에서 발생할 우려가 있 는 100 년 빈도를 초과하는 극치해면고가 형성되는 경우는 첨 두형 태풍에 의한 해일이 대조기 고조시에 조우한 상황에서 발생할 것으로 예상할 수 있다. 그러나 서해안의 경우 남해 안에 비해 위도가 높아 태풍강도가 다소 약해진 상태일 뿐 아 니라 시차특성에 따라 기압과 바람에 의한 최대해일이 동시 에 발생하지 않기에 남해안과 비교하여 상대적으로 해일고의 크기는 작게 형성된다.

\section{2) 지속형}

조석이 지배적인 서해안의 특성상 조석-해일 비선형성 및 그에 따른 조석변조해일 현상이 자주 나타난다. 서해안으로 진입한 태풍 뿐 아니라 남해안으로 진입한 태풍의 영향이 서 해안 지역에 조석변조해일의 형태로 나타나는 빈도도 높아 최 대해일고는 주로 저조시에 발생하는 해역이다. 지속형 태풍 해일은 태풍의 이동속도가 느리거나 태풍과의 이격거리가 멀 어 기압에 의한 해일효과가 크지 않고 바람에 의한 해일효과 가 지배적이기에 주로 저조시에 최대해일고가 형성되는 경향 이 있다. 그러나 저조시에 아무리 높은 해일고가 발생하더라 도 조석이 지배적인 서해안에서는 고극조위 발생과는 무관한 경우가 많다. 다만, 지속형 태풍해일은 해일지속시간이 길기 때문에 PRAPIROON(0012) 사례에서 볼 수 있듯이 최대해 일고는 저조에 발생하더라도 해일의 여파가 고조시까지 지속 되므로 대조기인 경우 이어지는 고조시 고극조위 발생 가능 성은 충분하다. 그러나 고조시 해일고의 크기가 크지 않기에 100 년 빈도를 초과하는 해면고 형성에는 역부족일 것으로 예 상된다.

\section{3) 전파형}

상기 두 가지 유형은 태풍통과에 따라 기압 및 바람에 의 해 해일이 발생하는 상황임에 반해 전파형 유형은 태풍이 도 달하기 전 또는 태풍진로에는 벗어나 있지만 발생된 해일파 가 전파되어 오는 경우에 해당된다. 따라서 해일고 자체는 크 지 않지만 해당해역의 조석상황과는 무관하게 전파되므로 고
조시에도 최대해일고가 발생할 수 있다. 가장 일반적으로 나 타나는 서해안 고극조위 발생패턴은 남해안 및 동해안과는 달 리 대형태풍에 의한 해일보다 백중사리와 같은 대조기 고조 시에 크지 않은 해일고가 겹쳐 고극조위가 형성되는 것은 주 지한 바와 같다. 이러한 백중사리시기에 태풍 WINNIE(9713) 와 같은 전파형 유형이 고조시에 겹쳐 역대 최고극조위가 형 성된 사례가 여기에 해당하며 서해안에서 범람을 발생시키는 가장 흔한 경우이며 이때 발생된 해면고는 관측자료기간에 해 당하는 50년 빈도 정도로 평가된다. 그러나 전파형 자체가 수 반하는 해일고 크기가 크지 않으므로 향후 이러한 유형으로 100 년 빈도를 초과하는 극치해면고 형성은 어려울 것으로 보 인다.

이상에서 살펴본 바와 같이 100 년 빈도를 초과하는 극치 해면고가 형성될 가능성은 첨두형이 가장 높지만 고조시 해 일고 자체가 저조시에 비해 작게 형성되는 경향이 있으며 남 해안에 비해 위도가 높은 관계로 태풍의 세력이 대체적으로 약해진 상태인 경우가 많다. 게다가 서해안 해일특성인 시차 현상에 따라 기압과 바람에 의한 최대해일 발생시점이 일치 하지 않아 남해안에 비해 약최고고조위를 크게 초과하는 극 치해면 발생은 제한적이라 평가된다.

\section{3 설계조위 산정법 반영}

국내에서 통용되는 폭풍해일 대책에 대한 설계조위 산정방 법 중 가장 일반적으로 사용되는 방안은 빈도별 해일고를 추 산한 후 약최고고조위에 해당 해일고를 가산하는 방법이다 (Kang and Kim, 2018). 조석이 지배적인 서해안의 경우 연 고극조위는 대부분 약최고고조위를 초과하는 대조기 고조시 에 발생한다. 그러나 대형태풍에 의한 서해안에서의 해일발 생은 저조시마다 해일고가 두드러지는 조석변조해일이 대부 분이고 매우 강하고 빠른 이동속도에 따라 발생하는 기압에 의한 첨두형 해일은 드문 탓에 최대해일고는 수심이 얕아지 는 저조시에 주로 발생하고 수심이 깊은 고조시에 발생하는 해일고는 비교적 작은 규모로 발생하는 경향이 있다. 이와 같 이 매우 큰 해일고가 고조시에 발생할 가능성이 적은 서해안 의 경우 저조시 크게 나타난 해일고를 단순히 고조위에 가산 하는 방법은 비현실적이라 할 수 있다. 또한 서해안의 경우 조석지배해역의 특성에 따라 100 년 빈도에 미달하는 극치해 면고가 형성되는 경우는 조위조건이 약최고고조위를 크게 초 과하는 시점에 크지 않은 해일고가 겹쳐 형성되는 것이 일반 적(Kang and Kim, 2018)이라고 알려져 있다. 이에 따라 현 행 방법에 의해 산정된 극치해면고는 서해안의 경우 특히 더 욱 과대산정되는 경향이 있게 된다. 따라서 해일고의 관측자 료 중 저조시에 발생한 최대해일고 자료, 특히 저조시 조석 변조해일이 잦은 지속형 태풍해일유형의 해일자료는 신중하 게 채택되어야 한다.

근본적으로 조석이 지배적인 서해안에서는 극치해면고 형 성에 있어 해일보다 조위의 기여도가 훨씬 클 뿐 아니라 조 
석-해일 비선형성 등 조석 관련 특성의 영향성이 크기 때문 에 조석과 해일을 분리하여 설계조위를 산정하는 방법 자체 에 문제가 있다. 따라서 설계조위 산정에 있어서 조석과 해 일의 결합확률을 산출하는 방법, 예를 들어 조석이 지배적인 해역의 극치해면 산정법(Kang et al., 2012)이 권장된다. 또 한 해일 수치모형에 있어서도 태풍의 궤적이나 이동속도를 포 함한 태풍의 제반 특성이 정확하게 모의되어야 함은 물론이 고 서해안의 경우 조석변조해일과 시차특성을 포함한 조석특 성이 정확하게 반영되어야 하므로 조석모의가 필수적으로 병 행되어야 한다.

\section{5. 결론 및 제언}

조석이 지배적인 서해안에서의 태풍해일 해석을 위해서는 조석 자체와 함께 조석-해일 비선형 특성 및 시차특성 등을 함께 고려해야 한다. 즉 서해안 지역에서 해일고는 저조시에 커지는 경향이 있고 태풍 통과 수 시간 경과 후에 최대해일 고가 형성되는 특성이 있다. 본 연구에서는 태풍해일의 유형 을 세 가지로 구분한 후 각 유형별 특성을 파악하였는데 태 풍의 이동속도와 이격거리에 따라 최대해일고 발생양상이 구 분되는 성향을 보이고 있다. 첨두형과 전파형은 조시와 무관 하게 최대해일고가 형성되지만, 지속형의 경우 주로 저조시 에 최대해일고가 발생하는 특성이 있다. 첨두형 태풍은 드물 게 발생하고 지속형은 최대해일고가 저조시에 발생하는 경향 이 있으며 전파형은 해일고 자체가 크지 않다. 따라서 과거 서해안에서 형성된 고극조위 실적을 보면 대형 태풍이 초래 한 큰 해일고로 인한 경우는 전무하다. 대부분 매우 높은 조 위상황에 크지 않은(태풍 또는 비태풍에 의한) 해일상황이 겹 쳐 이루어졌음을 볼 수 있다. 그러나 미래기후환경에서는 서 해안에서 강력한 태풍발생이 크게 증가할 것으로 예측되고 있 어 태풍해일의 영향성은 점차 커질 것으로 예상된다. 따라서 향후 재현기간 100 년 빈도를 초과하는 극치해면고는 높은 조 위상황에 중규모 이상의 첨두형 태풍해일이 겹치는 상황의 시 나리오를 상상할 수 있다. 비록 시차특성에 따라 남해안에 비 해 해일고 자체는 작게 형성되는 서해안이지만 지속적인 해 수면 상승과 갖은 대형태풍 및 높은 조위조건이 맞물릴 미래 상황에 대한 대처가 요구된다.

한편 태풍해일 수치모의를 통해 극치해면고를 산정할 경우 에도 가급적 다양한 조위조건을 함께 부여하여 조석-해일 비 선형성이 재현되도록 해야 하며, 태풍의 이동속도 및 최근접 거리와 같은 서해안 태풍해일특성에 따른 영향성을 주의 깊 게 고찰하여 설계조위 산정에 반영하여야 한다.

\section{References}

Clark, J.D. and Chu, P. (2002). Interannual variation of tropical cyclone activity over the central North Pacific. Journal of the
Meteorological Society of Japan, 80, 403-418.

Feng, X. and Tsimplis, M.N. (2014). Sea level extremes at the coasts of China. Journal of Geophysical Research: Oceans, 119, 1593-1608.

Flowerdew, J., Horsburgh, K., Wilson, C. and Mylne, K. (2010). Development and evaluation of an ensemble forecasting system for coastal storm surges. Quarterly Journal of the Royal Meteorological Society, 136, 1444-1456.

Horsburgh, K.J. and Wilson, C. (2007). Tide-surge interaction and its role in the distribution of surge residuals in the North Sea. J. of Geophysical Research, 112, 1-13.

IPCC (2013). Climate change 2014. Cambridge University Press.

Kang, J.W. (2015). Typhoon-surge characteristics in relation with the tide-surge interaction. Journal of Korean Society of Coastal and Ocean Eng., 27(1), 25-37 (in Korean).

Kang, J.W. and Kim, Y.-S. (2016). Frequency analysis on surge height by numerical simulation of a standard typhoon. Journal of Korean Society of Coastal and Ocean Eng., 28(5), 284-291 (in Korean).

Kang, J.W. and Kim, Y.-S. (2018). Estimation of extreme sea levels reflecting tide-surge characteristics. Journal of Korean Society of Coastal and Ocean Eng., 30(3), 103-113 (in Korean).

Kang, J.W., Kim, Y.-S., Cho, H. and Shim, J.-S. (2012). Estimation of extreme sea levels at tide-dominated coastal zone. Journal of Korean Society of Coastal and Ocean Eng., 24(6), 381-389 (in Korean).

Kang, J.W. and Park, S.-J. (2017). Analysis of typhoon-surge characteristics by numerical simulation near Gori nuclear power plant. Journal of Advanced Engineering and Technology, 10(4), 457-464 (in Korean).

Kang, J.W., Kim, Y.-S., Yoon, Y.-K. and Shim, J.-S. (2014). Appearance of tide-surge interaction along the West/South Coasts. Journal of Korean Society of Coastal and Ocean Eng., 26(6), 352-358 (in Korean).

Klotzbach, P.J. (2006). Trends in global tropical cyclone activity over the past twenty years (1986-2005). Geophysical Research, 33.

Landsea, C.W., Nicholls, N., Gray, W.M. and Avila, L.A. (1996). Downward trends in the frequency of intense Atlantic hurricanes during the past five decades. Geophysical Research, 23, 1697-1700.

Liu, X., Jiang, W., Yang, B. and Baugh, J. (2018). Numerical study on factors influencing typhoon-induced storm surge distribution in Zhanjiang Harbor. Estuarine, Coastal and Shelf Science, 215, 39-51.

Moon, I.-J., Oh, I.S., Murty, T. and Youn, Y.-H. (2003). Causes of the unusual coastal flooding generated by typhoon Winnie on the West Coast of Korea. Natural Hazards, 29, 485-500.

Mori, N. and Takemi, T. (2016). Impact assessment of coastal hazards due to future changes of tropical cyclones in the North Pacific Ocean. Weather and Climate Extremes, 11, 53-69.

Oh, S.M. and Moon, I.-J. (2013). Typhoon and storm surge intensity changes in a warming climate around the Korean Peninsula. 
Natural Hazards, 66, 1405-1429.

Seo, S.N. and Kim, S.I. (2014). Storm surges in West Coast of Korea by typhoon BOLAVEN (1215). Journal of Korean Society of Coastal and Ocean Eng., 26(1), 41-48 (in Korean).

Wuxi, Q., Li, J. and Nie, B. (2018). Effects of tide-surge interaction and wave set-up/set-down on surge: case studies of tropical cyclones landing China's Zhe-Min coast. Theoretical \& Applied Mechanics Letters, 8, 153-159.
Yang, J.-A., Kim, S., Mori, N. and Mase, H. (2018). Assessment of long-term impact of storm surges around the Korean Peninsula based on a large ensemble of climate projections. Coastal Engineering, 142, 1-8.

Received 3 April, 2019

Accepted 18 April, 2019 